\title{
Experimental Studies on TVOC Concentrations and their Relationships with Indoor Comfort Parameters
}

\author{
VASILICA VASILE ${ }^{1,2 *}$, CRISTIAN PETCU ${ }^{1}$, VLAD IORDACHE ${ }^{2}$ \\ ${ }^{1}$ National Institute for Research and Development in Construction, Urban Planning and Sustainable Spatial Development \\ „URBAN-INCERC”, 266 Pantelimon Road, 021652, Bucharest, Romania \\ ${ }^{2}$ Technical University of Civil Engineering, Faculty of Building Services, 66 Pache Protopopescu Blvd., 021407, \\ Bucharest, Romania
}

\begin{abstract}
Indoor air quality (IAQ) remains a very important issue because it can significantly affect people's health, comfort and productivity. Volatile organic compounds (VOCs) comprise an important group of chemicals that are commonly present in indoor air. They are related to the sick building syndrome (SBS) and exposure to VOCs is of considerable concern due to their potential chronic and acute health outcomes which includes eye irritation, nose and throat discomfort, headache, allergic skin reaction, nausea, fatigue, or dizziness. Most of the times the effects of VOCs on human health are amplified by indoor conditions such as temperature and humidity. The paper presents the findings of the analysis of the relationship between total volatile organic compounds (TVOC) concentrations and their influencing factors like indoor comfort parameters (temperature and relative humidity) and the type of indoor spaces (offices, residential and educational).
\end{abstract}

Keywords: TVOC concentrations, indoor comfort parameters, Pearson correlation coefficients

Many efforts have been made, during the last decades, to protect populations from harmful exposure to outdoor pollutants, networks of air monitoring stations being located in strategic places in order to provide information on the pollutant concentrations to which humans are exposed [1]. However, people spend more than $80 \%$ of their time in various indoor spaces (i.e. homes, offices, educational, etc.) [2-6] and the quality of indoor air, is an important factor influencing human health. Indoor air pollution is widely recognized as one of the most serious potential environmental risks to human health. The World Health Organization recognized indoor-air pollution as the 8th most important factor for health and responsible for $2.7 \%$ of the global burden of diseases. Indoor air quality (IAQ) remains a very important issue because it can significantly affect people's health, comfort, satisfaction and productivity [7-8]. Volatile organic compounds (VOCs) comprise an important group of chemicals that are commonly present in indoor air and constitute one of the main sources of indoors pollution [9]. These compounds are described by its main physical characteristics such as boiling range and vapour pressure, the most referenced being benzene, toluene, ethylbenzene and xylene (BTEX), polyaromatic hydrocarbons (PAHs) and formaldehyde [10].

There have been many studies on air pollution in urban areas [11-14] and their transport to buildings [15-18], but fewer studies have been conducted on VOCs. However, the effects of VOCs on human health show that their importance is not at all lower and it has to cause of concern firstly due to their role in formation of ground level ozone and smog, and secondly due to some of them being carcinogenic, mutagenic and teratogenic in nature [7]. Exposure to VOCs is also of considerable concern due to their potential chronic and acute health outcomes [2, 19-20]. Key signs or symptoms associated with exposure to VOCs include eye irritation, nose and throat discomfort, headache, allergic skin reaction, nausea, fatigue, or dizziness. VOCs are produced by anthropogenic activities such as transport or industry, and by biogenic activities of plants [1,10], but also various materials such as carpets, wallpaper, curtains, paper products, and electronic equipment release VOCs, with newer materials emitting highest concentrations. Most of the times the effects of VOCs on human health are amplified by indoor conditions such as temperature and humidity [21]. VOCs could be at the base of various discomforts inside the buildings and lead to what is called sick building syndrome (SBS) in scientific literature [4, 22]. Understanding the evolution of TVOCs concentration inside buildings is the basis for predicting this variation and a correct ventilation strategy for interior spaces.

In our study we propose to answer in this new research direction, related to the explanation of the variation of the indoor concentration of TCOV. Thus, the main objective of this paper is to analyze, by monitoring and statistical interpretation, the correlation between TVOC concentrations and other comfort parameters simple to determine as temperature $-\theta$ and relative humidity - $\phi$ under monitoring conditions, for different type of spaces (offices, residential and educational), located in urban area of Bucharest city (fig.1). Basic statistics and correlation analysis were applied in the analysis data.

*email: vasile@incd.ro, Phone: 021/255.12.13;0723.536.002 


\section{Experimental part}

Spaces description

The studies were performed in spaces with different types of activities, located in districts 2 and 3 of urban area of Bucharest, the largest city and the capital of Romania (fig.1).

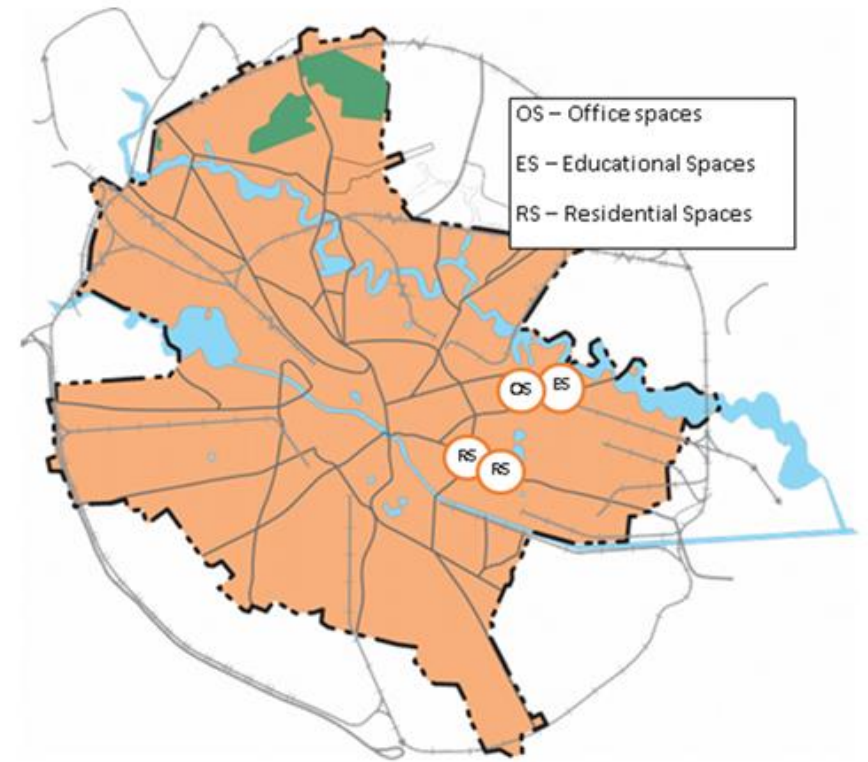

Fig.1 Locations of the monitored spaces from Bucharest city

The investigated segment of the monitoring activity consisted of three office spaces, three residential spaces (bedrooms and kitchens) and six educational spaces (two kindergartens, three general schools and a high school). First test segment, consisted of three office spaces with drawings presented in fig. 2 , is located upstairs of the building.
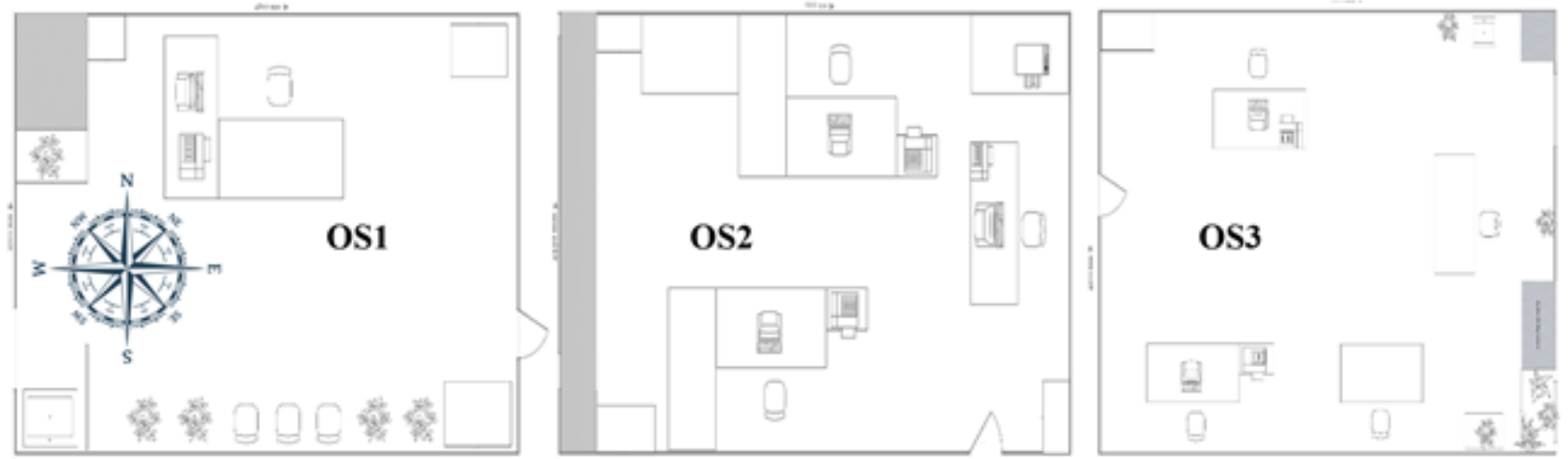

Fig.2 Drawings of the monitored office spaces (OS)

The walls of all three offices are polished using aqueous dispersion paint and the floor is covered with glazed tiles in OS1 and OS2, respectively PVC carpet in OS3. The windows and doors of the OS1 and OS2 are made of PVC profiles. OS3 has PVC windows and plywood door. The measurements were performed in normal operating conditions of the spaces, and from time to time the number of residents may vary as persons may temporarily leave or enter the office. The fresh air is provided exclusively by infiltration/exfiltration and natural ventilation rate is occasionally increased by temporarily opening the mobile elements of building envelope.

As pollutants from exterior sources can affect the interior air quality [22-23], the residential spaces (RS) that were investigated from the point of view of indoor air quality were selected based on the area where they are located, being selected a building located relatively far from the traffic (RS1) and a building located next to a high traffic boulevard (RS2 and RS3). Interior spaces (with drawings in fig.3) were chosen on the assumption that in the kitchen areas there are many sources of emissions and the resting area (bedroom) is the most importance space, where emissions should be minimized. Pollutant concentration measurements were performed in situ, both in the absence of inhabitants and in the case of them carrying out normal activities, while the space ventilation was of natural type.

RS1 is an apartment in a four levels building. The windows are made of PVC profiles with double glazing and the doors are wooden made. For the decoration of bedroom (RB1) walls interior waterborne paint was used and the floor is made of solid wood flooring. The kitchen (RK1) has both walls and floors finished with glazed ceramic tiles. RS2 (RB2 and RK2) are located at second floor and RS3 (RB3 and RK3), at ninth floor of the building. The windows are 
made from AL and PVC profiles and the doors are wooden made. The waterborne paints were used for decoration of wall bedrooms and the glazed ceramic tiles for walls and floors of kitchens.
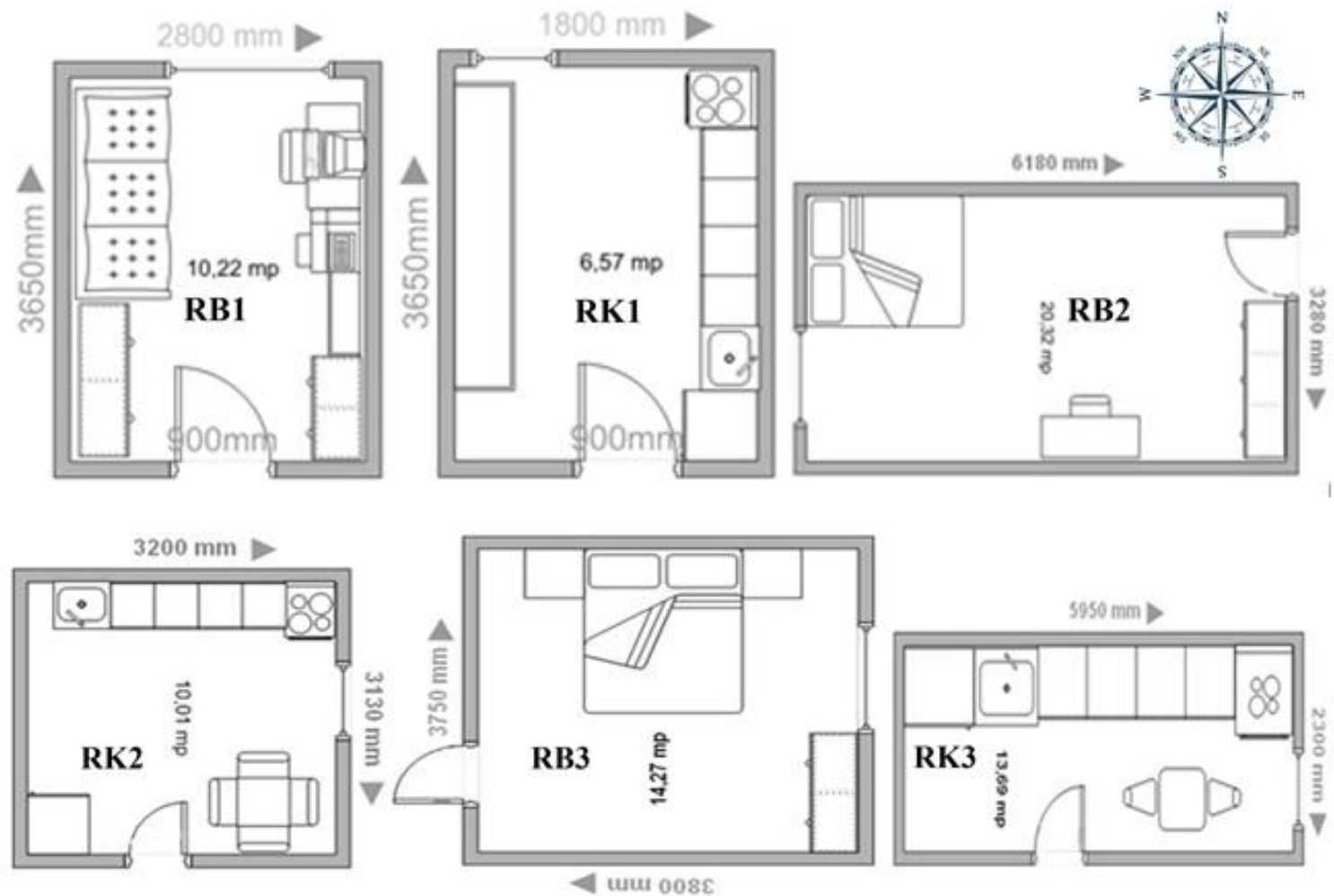

Fig.3 Drawings of the monitored residential spaces (bedrooms, RB, and kitchens, RK)

The investigated educational spaces (ES) consisted of two kindergartens (ES1 and ES2), three general schools (ES3, ES4 and ES5) and a high school (ES6), where children from 3 to 17 years of age perform daily activities. The walls of the ES were finished with white-colored water dispersion, and the flooring was made of laminate flooring. The windows and doors are made of PVC profiles.

\section{Instrumentation}

The measurement of TVOC concentrations, $\mathrm{C}_{\mathrm{TVOC}}$, in $\mathrm{ppm}$, was performed using a direct detection method and the portable data-logging detector IQ-610 probe (GrayWolf Sensing Solutions, USA), in range 20 - 20000ppb, with a resolution of $1 \mathrm{ppb}$. The operating principle is based on electronic detection, having a photo-ionization detector (PID) sensor, consisting of a light source (lamp) with a specific potential ionization measured in electron volts $(10.6 \mathrm{eV})$. The equipment has inside sensors, thermal resistance Pt100, for the measurement of the temperature, $\Theta,{ }^{\circ} \mathrm{C}$, between $10^{\circ} \mathrm{C}$ and $+70^{\circ} \mathrm{C}$, with a precision of $\pm 0.3^{\circ} \mathrm{C}$ and of the relative humidity, $\varphi, \%$, (using capacitive principle), between 0 and $100 \%$, with a precision of $\pm 2 \%$. The equipment was calibrated before the measurements.

Experimental program: The experimental program is presented in table 1.

Table 1

CHARACTERISTICS OF THE EXPERIMENTAL PROGRAM

\begin{tabular}{|c|c|c|c|}
\hline \multirow{2}{*}{\begin{tabular}{c} 
Characteristic \\
\cline { 2 - 4 }
\end{tabular}} & Office spaces & Residential spaces & Educational spaces \\
\hline $\begin{array}{c}\text { Sampling height above } \\
\text { the floor level, } \mathrm{m}\end{array}$ & 1.20 & 1.20 & 1.20 \\
\hline $\begin{array}{c}\text { Sampling interval, min } \\
\text { Daily measurement } \\
\text { period }\end{array}$ & $\begin{array}{c}09: 00 \mathrm{am}-01: 00 \mathrm{pm}, \\
\text { working days }\end{array}$ & $\begin{array}{c}16: 00 \mathrm{pm}-20: 00 \mathrm{pm} \\
\text { weekdays and weekend days }\end{array}$ & $\begin{array}{c}1 \text { hour } \\
\text { weekdays }\end{array}$ \\
\hline $\begin{array}{c}\text { Sampling point } \\
\text { center of the room }\end{array}$ & center of the room & $\begin{array}{c}\text { located in the area behind } \\
\text { the classroom, } 1 \text { meter away } \\
\text { from the wall }\end{array}$ \\
\hline $\begin{array}{c}\text { Monitoring campaign } \\
\text { period }\end{array}$ & March - May 2012 & August - September 2013 & October 2015 \\
\hline
\end{tabular}

\section{Results and discussions}

The obtained values in OS, represented in fig.4, vary from $0.17 \mathrm{ppm}$ to $0.3 \mathrm{ppm}\left(390.1 \div 688.5 \mu \mathrm{g} / \mathrm{m}^{3}\right.$ isobutylene units), the values from RS between $0.1 \mathrm{ppm}$ to $0.38 \mathrm{ppm}\left(229.5-872.1 \mu \mathrm{g} / \mathrm{m}^{3}\right.$ isobutylene units), and in ES from $0.34 \mathrm{ppm}$ to $1.11 \mathrm{ppm}\left(780.3-2,547.3 \mu \mathrm{g} / \mathrm{m}^{3}\right.$ isobutylene units). It can observe that the lowest values were obtained in 
RB1, 0.1ppm, and in OS2, 0.17ppm, and the highest values were obtained in ES, particular in two of general schools, $1.11 \mathrm{ppm}$ in ES3, and 1.1ppm in ES5.

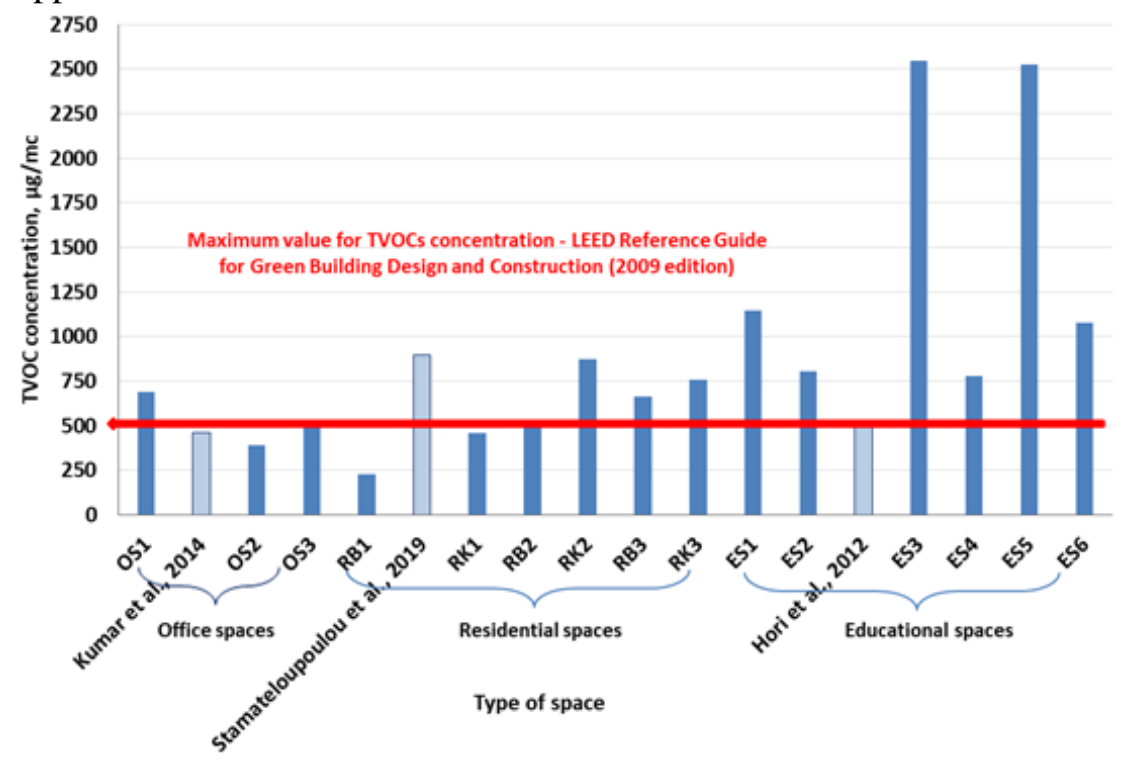

Fig.4 TVOC concentrations (average values) in investigated spaces

Our results are comparable with the similar studies conducted internationally. A recent article [2] reported the mean concentration of TVOC as $465.8 \mu \mathrm{g} / \mathrm{m}^{3}\left(145.3 \div 1503.2 \mu \mathrm{g} / \mathrm{m}^{3}\right)$ in winter and $321.8 \mu \mathrm{g} / \mathrm{m}^{3}\left(90.7 \div 1,100.9 \mu \mathrm{g} / \mathrm{m}^{3}\right)$ in summer for indoor air of the library of Jawaharlal Nehru University, New Delhi, a range of 100 and $538 \mu \mathrm{g} / \mathrm{m}^{3}$ for TVOC concentrations was reported in indoor air of some Japanese University classrooms [24]. Sarkhosh and colleagues [25] measured the concentrations in range from 113.4 to $486.3 \mathrm{ppb}\left(227-973 \mu \mathrm{g} / \mathrm{m}^{3}\right.$ isobutylene units) in photocopy centers and Chan and colleagues [26] recorded TVOC concentrations in new hotels' guest rooms of the factory region which varied between 416 and $2900 \mu \mathrm{g} / \mathrm{m}^{3}$. Recently, Stamateloupoulou et al. [27] reported the concentrations of TVOC in range from 24 to $890 \mu \mathrm{g} / \mathrm{m}^{3}$ in residences with young children, and Liu et al. [28], the mean TVOC concentrations of $89.7 \mu \mathrm{g} / \mathrm{m}^{3}$ in underground parking garages with traffic volume. It is interesting to mention that the maximum value for TVOCs concentration, given in the LEED Reference Guide for Green Building Design and Construction (2009 edition), is of $500 \mu \mathrm{g} / \mathrm{m}^{3}$ (for measurements in a minimum period of 4 hours).

From the point of view of temperature, represented in fig.5, the highest values are registered in RS, between $25.2^{\circ} \mathrm{C}$ and $30.1{ }^{\circ} \mathrm{C}$, following by the values from ES, between $24.6^{\circ} \mathrm{C}$ and $28.7^{\circ} \mathrm{C}$, the both higher than the guideline levels $\left(23.5 \div 25.5^{\circ} \mathrm{C}\right)$ of the American Society of Heating, Refrigerating and Air-conditioning Engineers (ASHRAE), and the lowest values are in $\mathrm{OS}$, from $22.3^{\circ} \mathrm{C}$ to $23.1^{\circ} \mathrm{C}$, under the limits of ASHRAE.

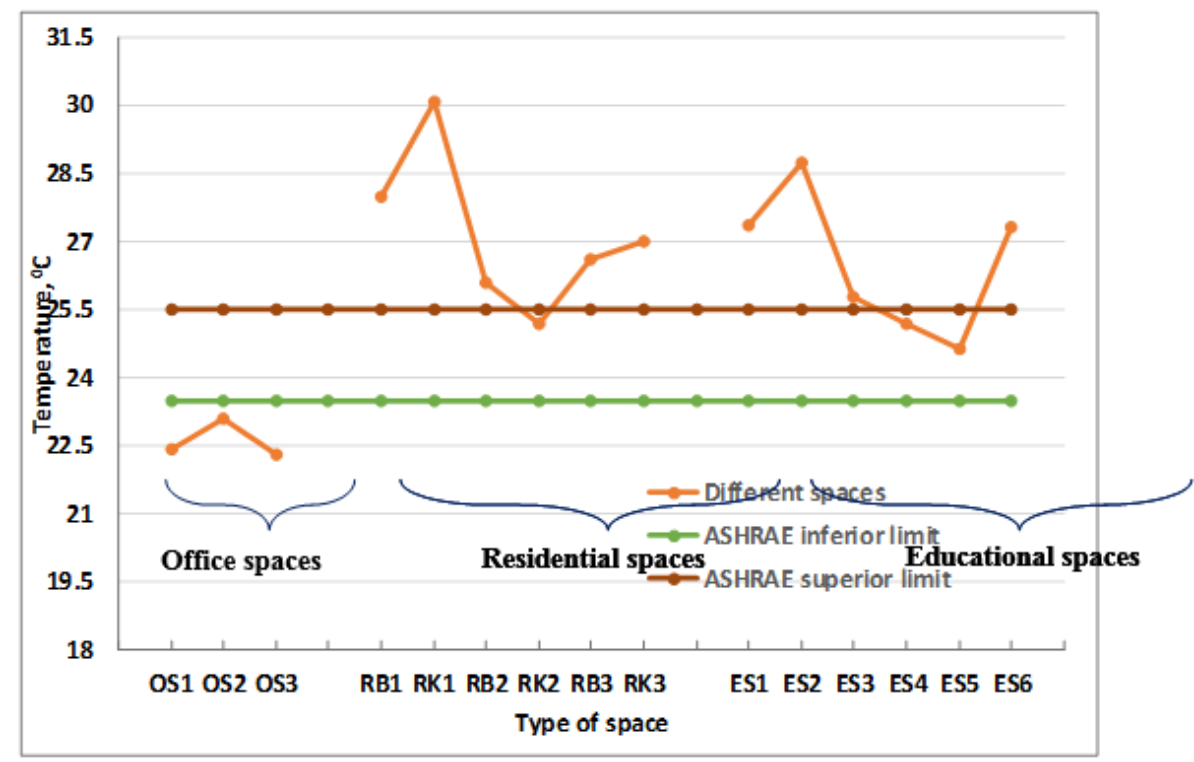

Fig.5 Average Indoor Temperature during TCOV measurements campaign

The values of relative humidity, represented in fig.6, are in range of $29.5 \%$ and $36.9 \%$ for OS, between $44.5 \%$ and $54.1 \%$ for RS and from $37.9 \%$ and $58.6 \%$ for ES, the highest values, but in limits $(30 \div 60 \%)$ indicated by the guideline levels of the ASHRAE. The lowest values were registered in the OS, while the highest values both in RS and ES. 


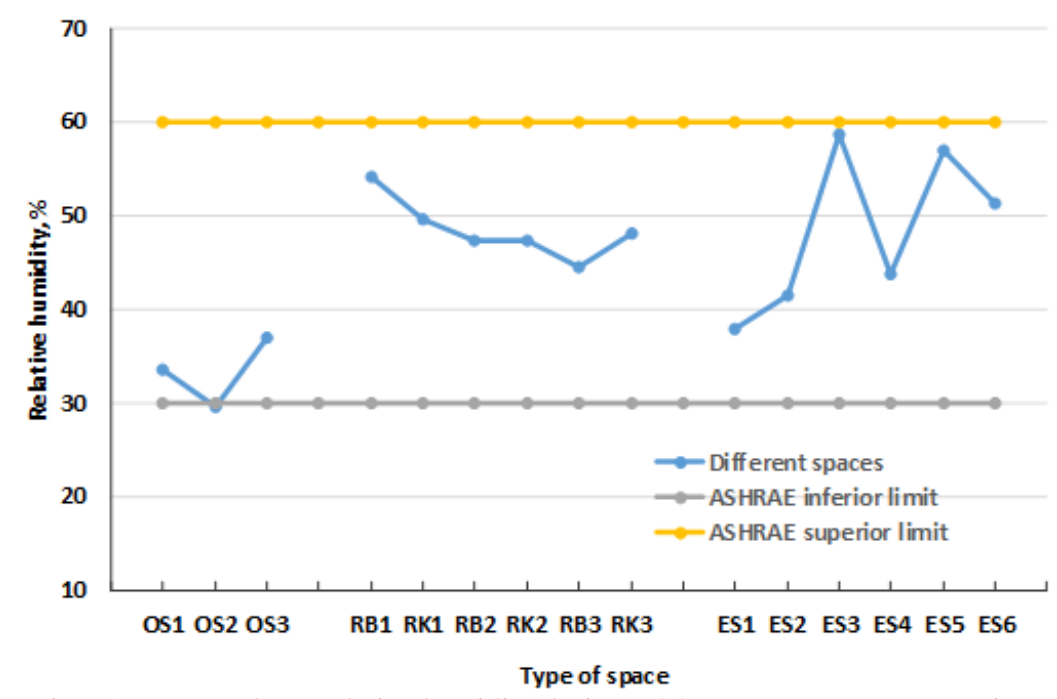

Fig.6 Average Indoor Relative humidity during TCOV measurements campaign

In order to answer of new research direction, respectively the explanation of the variation of the indoor concentration of TCOV with indoor comfort parameters - temperature and relative humidity, in fig.7-8 are represented, for example, the relationships between them, for OS and RS (RK).

As it can see from fig.7a, there is an inverse correlation between TVOC concentration and temperature, a strong one for all office spaces and, respectively, no correlation for RS (RK), in fig.7b.
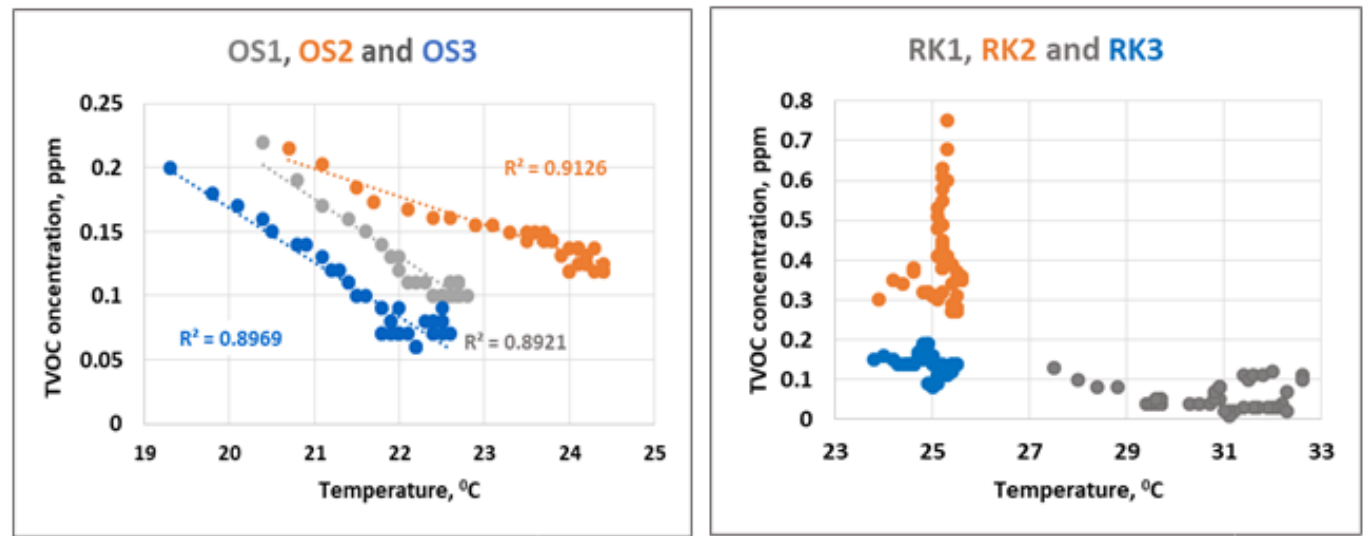

a)

b)

Fig.7 a) Inverse correlation $\mathrm{C}_{\mathrm{Tvoc}} / \Theta$ for OS; b) No correlation $\mathrm{C}_{\mathrm{TVOC}} / \mathrm{\Theta}$ for $\mathrm{RK}$

Between TVOC concentration and relative humidity, as it can see in fig.8a, there is a direct correlation, a stronger correlation for offices OS2 and OS3, and, respectively, no correlation for RS (RK), in fig.8b.
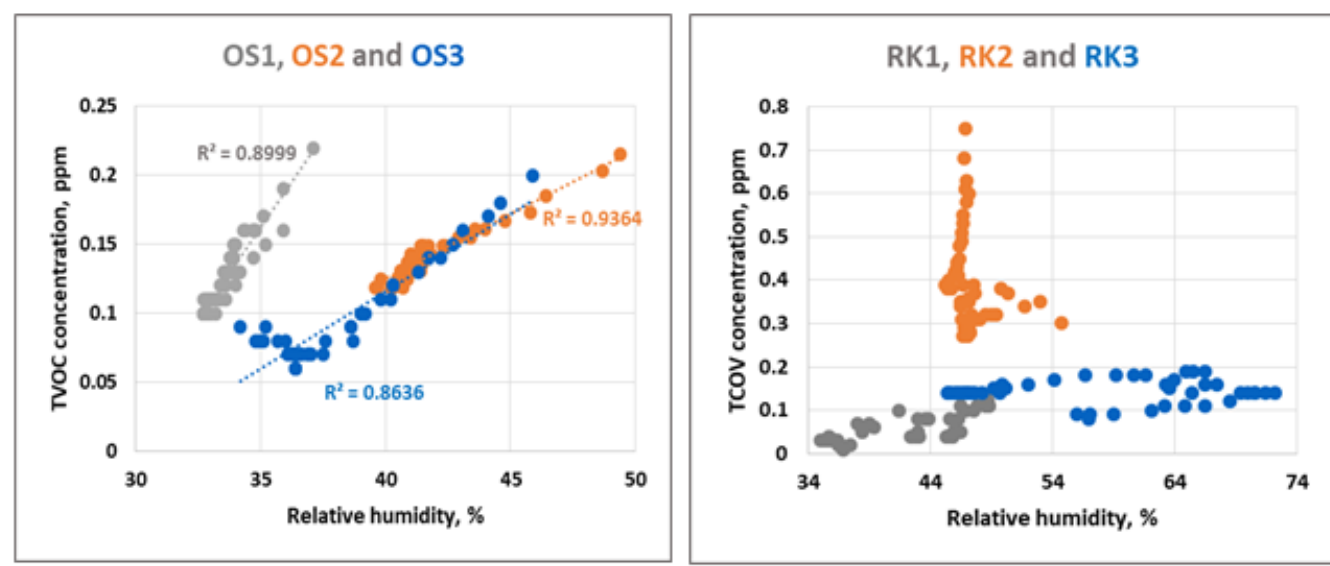

a)

Fig.8 a) Direct correlation $\mathrm{C}_{\mathrm{TVOC}} / \varphi$ for OS ; b) No correlation $\mathrm{C}_{\mathrm{TVOC}} / \varphi$ for RK

The correlations between TVOC concentration and the environmental parameters (temperature and relative humidity) are varied in scientific literature. Thus, the direct correlations between TVOC concentration and relative humidity are confirmed by other previous studies, such as Tao et al. [29], while the inverse correlation between TCOV concentration and temperature, by Adebayo et al. [7]. The inverse correlation between temperature and relative humidity is confirmed by Bucur et al. [21] and other studies [11, 30]. 
In order to better understand if the TVOC concentration and the analyzed parameter vary simultaneously or not, we have calculated the Pearson correlation coefficient. This coefficient is calculated as the ratio between (1) the covariance of the TVOC concentration and the analyzed parameter and (2) the product of the standard deviations of the TVOC concentration and the analyzed parameter. The correlation coefficient varies between -1 and 1 , which means that when is close to zero then there is no correlation between the two parameters and when it is close to the limits of this interval then the two parameters are correlated (the sign "+" indicates a direct correlation and both parameters increase or decrease simultaneously) and the sign "-"indicates there is an inverse correlation - when one parameter increases the other one decreases). The obtained values of the Pearson correlation coefficients for TCOV concentration and temperature $\left(\mathrm{C}_{\mathrm{TCOV}} / \theta\right)$, TVOC concentration and relative humidity $\left(\mathrm{C}_{\mathrm{TCOV}} / \phi\right)$, temperature and relative humidity $(\theta / \phi)$ in the investigated spaces are presented in table 2.

Table 2

PEARSON CORRELATION COEFFICIENTS FOR THE INVESTIGATED SPACES

\begin{tabular}{|c|c|c|c|}
\hline \multirow{2}{*}{$\begin{array}{c}\text { Analysed } \\
\text { space }\end{array}$} & \multicolumn{3}{|c|}{ Correlation coefficients, $\rho(-)$} \\
\cline { 2 - 4 } & $\mathrm{C}_{\text {Tvoc }} \boldsymbol{\theta}$ & $\mathrm{C}_{\text {Tvoc }} \boldsymbol{\varphi}$ & $\theta-\varphi$ \\
\hline & & & -0.827 \\
\hline OS1 & -0.958 & 0.948 & -0.971 \\
\hline OS2 & -0.956 & 0.967 & -0.964 \\
\hline OS3 & -0.947 & 0.929 & -0.884 \\
\hline RB1 & & & -0.556 \\
\hline RK1 & -0.652 & 0.915 & -0.030 \\
\hline RB2 & -0.046 & 0.636 & -0.813 \\
\hline RK2 & 0.295 & 0.214 & -0.981 \\
\hline RB3 & 0.040 & -0.238 & 0.828 \\
\hline RK3 & -0.492 & 0.571 & -0.958 \\
\hline & -0.251 & 0.069 & -0.955 \\
\hline ES1 & & & -0.951 \\
\hline ES2 & -0.962 & 0.899 & 0.106 \\
\hline ES3 & -0.949 & 0.967 & -0.922 \\
\hline ES4 & -0.839 & 0.898 & -0.830 \\
\hline ES5 & -0.166 & 0.951 & 0.995 \\
\hline ES6 & -0.883 & 0.918 & \\
\hline
\end{tabular}

As it can see in the table 2, for all OS there is a great inverse correlation between TCOV concentration and temperature $\left(\mathrm{C}_{\mathrm{TCOV}} / \theta\right)$, and between temperature and relative humidity $(\theta / \phi)$, while between TVOC concentration and relative humidity $\left(\mathrm{C}_{\mathrm{TCOV}} / \phi\right)$ there is a great direct correlation. The same, for ES, except for ES4, where is confirmed the direct correlation between TVOC concentration and relative humidity. In RS it is a different situation, especially in RK where, mainly because of cooking activities, the correlations found in other spaces are not valid. Temperature has already been found to significantly influence the formation of other outdoor and indoor pollutants [11,30].

The obtained mean values of the Pearson correlation coefficients for TCOV concentration and temperature $\left(\mathrm{C}_{\mathrm{TCOV}}\right.$ $-\theta)$, TVOC concentration and relative humidity $\left(\mathrm{C}_{\mathrm{TCOV}}-\phi\right)$, temperature and relative humidity $(\theta-\phi)$ in the investigated spaces are presented in figure $9 \mathrm{a}, \mathrm{b}$ and $\mathrm{c}$.
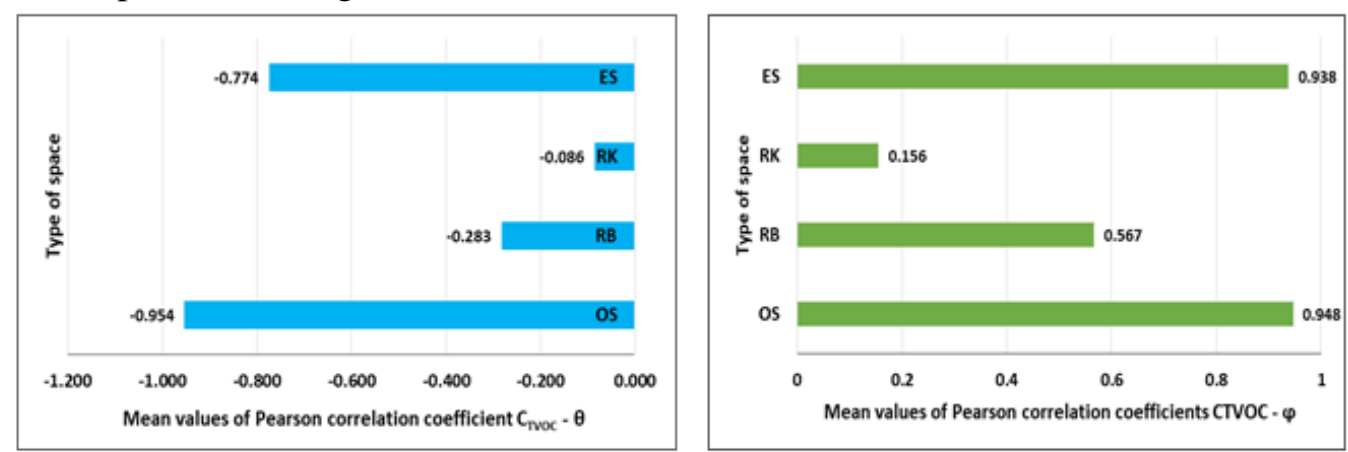

a)

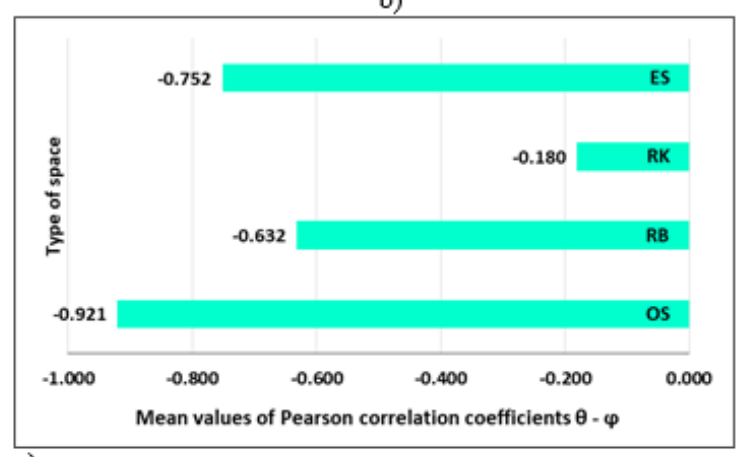

c)

Fig.9 Mean values of Pearson correlation coefficients 
The mean values of Pearson correlation coefficients, represented in fig.9, show the strong inverse correlation between TVOC concentrations and temperature and a strong direct correlation between TVOC concentrations and relative humidity in OS and ES. But in RS, especially in the RK, there is not a correlation between the TVOC concentrations and the indoor comfort parameters - temperature and humidity.

\section{Conclusions}

The paper presents the obtained results, by monitoring and statistical interpretation, of the correlation between TVOC concentrations and environmental parameters (temperature and relative humidity) in different type of spaces (offices, residential and educational), located in urban area of Bucharest city.

The TVOC concentrations varied from $0.17 \mathrm{pm}$ to $0.3 \mathrm{ppm}\left(390.1688 .5 \mu \mathrm{g} / \mathrm{m}^{3}\right.$ isobutylene units) in office spaces, between $0.1 \mathrm{pm}$ to $0.38 \mathrm{ppm}\left(229.5 \div 872.1 \mu \mathrm{g} / \mathrm{m}^{3}\right.$ isobutylene units) in residential spaces, and from $0.34 \mathrm{ppm}$ to $1.11 \mathrm{ppm}\left(780.3 \div 2,547.3 \mu \mathrm{g} / \mathrm{m}^{3}\right.$ isobutylene units) in educational spaces, being the highest ones. From the point of view of temperature, the highest values are registered in residential spaces, between $25.2^{\circ} \mathrm{C}$ and $30.1^{\circ} \mathrm{C}$, following by the values from educational spaces, between $24.6^{\circ} \mathrm{C}$ and $28.7^{\circ} \mathrm{C}$, the both higher than the guideline levels $(23.5$ $25.5^{\circ} \mathrm{C}$ ) of the ASHRAE, and the lowest values are in office spaces, from $22.3^{\circ} \mathrm{C}$ to $23.1^{\circ} \mathrm{C}$, under the limits of ASHRAE. The values of relative humidity, are in range of $29.5 \%$ and $36.9 \%$ for office spaces, between $44.5 \%$ and $54.1 \%$ for residential spaces and from $37.9 \%$ and $58.6 \%$ for educational spaces, the highest values, but in limits $(30 \div 60 \%)$ indicated by the guideline levels of ASHRAE.

The Pearson correlation coefficients showed that for all office spaces there is a great inverse correlation between TCOV concentration and temperature $\left(\mathrm{C}_{\mathrm{TCOV}} / \theta\right)$, and between temperature and relative humidity $(\theta / \phi)$, while between TVOC concentration and relative humidity $\left(\mathrm{C}_{\mathrm{TCOV}} / \phi\right)$ there is a great direct correlation. The same, for the educational spaces, except for ES4, where is confirmed the direct correlation between TVOC concentration and relative humidity. In the residential spaces it is a different situation, especially in the kitchen spaces where, mainly because of cooking activities, the correlations found in other spaces are not valid. To avoid any health risks caused by poor indoor air quality are needed preventive measures for the reduction of effective sources. To reduce VOC levels in the indoor environment it will be necessary two type of measures: to eliminate the sources of chemicals through a better choice of construction/furnishing materials and to increase the ventilation rate.

Acknowledgements: The authors acknowledge the financial support from The Ministry of Research and Innovation through the project PN 0914 04 02: "Concepts of making green buildings, in embodiments and of environmentally friendly materials, with low energy" and the project PN 19 3304 02: "Sustainable solutions to ensure the health and safety of population in concept of open innovation and environmental protection".

\section{References}

1. SLEZACOVA, K., MORAIS, S., DO CARMO PEREIRA, M., Indoor Air Pollutants: Relevant Aspects and Health Impacts, Environmental Health-Emerging Issues and Practice, InTech, Oosthiuzen, J., Perth Australia, 2012, p. 125

2. KUMAR, A., SINGH, B.P., PUNIA, M., SINGH, D., KUMAR, K., JAIN, V. K., Environ Sci Pollut Res, 21, 2014 , p. 2240

3. KIM, M., BRAATZ, R.D., KIM, J.T., YOO, C.K., Building and Environment, 92, 2015, p. 407

4. CANHA, N., LAGE, J., CANDEIAS, S., ALVES, C., ALMEIDA, S. M., Atmospheric Pollution Research 8, 2017 , p. 1132

5. GUYOT, G., SHERMAN, M.H., WALKER, I.S., Energy \& Buildings, 165, 2018, p. 416

6. LIU, J., XILEI, D., XIANGDONG, L., SUSU, J., JINGJING, P., YUEXIA, S., DAYI, L., XIONG, S., HEJIANG, S., HAIGUO, Y., KAILIANG, H., HONGWEI, T., YAO, G., YIWEN, J., Building and Environment, 142, 2018, p. 119

7. ADEBAYO, O.J., ABOSEDE, O.O., SUNDAY, F.B., AYOOLUWA, A., ADETAYO, A.J., ADEMOLA, S.J., ALABA, A.F., International Journal of Civil Engineering and Technology, 9, 2018, p. 2872

8. CHENG, Y., ZHANG, S., HUAN, C., OLADOKUN, M.O., LINE, Z., Building and Environment, 147, 2019, p. 11

9. VOINEA, S., AXENIE, T., SERBAN, A., NICHITA, C., Rev.Chim.(Bucharest), 69, no.12, 2018, p.3616

10. GUNAWARDENA, K., STEEMERS, K., Building and Environment, 148, 2019, p. 478

11. IORDACHE, V., Mathematical Modeling in Civil Engineering, 1-2, 2011, p.141

12. BĂRBULESCU, A., BARBEŞ, L., Rev. Chim. (Bucharest), 64, no. 7, 2013, p. 747

13. CAPATINA, C., SIMIONESCU, C.M., DADALAU, N., CIRTINA, D., Rev.Chim.(Bucharest), 67, no.7, 2016, p.1247

14. CROITORU, C., NĂSTASE, I., E3S Web of Conferences, 32, EENVIRO 2017, doi.org/10.1051/e3sconf/20183201010

15. BLONDEAU, P., IORDACHE, V., POUPARD, O., GENIN, D., ALLARD, F., Indoor Air, 15, 2005 , p. 2

16. GHIAUȘ, C., IORDACHE, V., ALLARD, F., BLONDEAU, P., Natural ventilation in the Environment: Assessment and Design, (Eds)

Allard F and Ghiaus C., 2012

17. DAI, X., LIU, J., LI, X., ZHAO, L., Building and Environment, 144, 2018, p. 238

18. SHI, S., Building and Environment, 131, 2018, p.154

19. LEE, J.Y., LEE, S.B., BAE, G.N., Atmospheric Pollution Research, 5, 2014, p. 616

20. HUANG, L., QIAN, H., DENG, S., GUO, J., LI, Y., ZHAO, W., YUE, Y., Atmospheric Environment, 188, 2018, p.1

21. BUCUR, E., DĂNET, A.F., LEHR, C.B., LEHR, E., VASILE, A., Rev.Chim.(Bucharest), 67, no. 8, 2016, p.1421

22. KELLY, F.J., FUSSELL, J.C., Atmospheric Environment, 200, 2019, p. 90

23. SALTHAMMER, T., SCHIEWECK, A., GU, J., AMERI, S., UHDE, E., Building and Environment 143, 2018 , p. 661

24. HORI, H., ISHIMATSU, S., FUETA, Y., ISHIDAO, T., Environ Health Prev Med., 2012, doi:10.1007/s12199-012-0319-1

25. SARKHOSH, M., MAHVI, A.H., ZARE, M.R., FAKHRI, Y., SHAMSOLAHI, H.R., Atmos Environ, 63, 2012, p. 307

26. CHAN, W., LEE, S., CHEN, Y., MAK, B., WONG, K. CHAN, C., Int J Hosp Manag, 28, 2009, p. 26

27. STAMATElOPOUlOU, A., ASIMAKOPOULOS, D.N., MAGGOS, T., Building and Environment, 150, 2019, p.233 
28. LIU, Z., YIN, H., MA, S., JIN, G., JUN, G., DING, W., Environmental Pollution, 2019, doi: https://doi.org/10.1016/j.envpol.2019.01.095.

29. TAO, H., FAN, Y., LI, X., ZHANG, Z., HOU, W., Building and Environment, 85, 2015, p. 85

30. NĂSTASE, I., IORDACHE, V., COLDA, I., Clima 2010: 10th REHVA World Congress: Sustainable Energy Use in Buildings: 9-12 May 2010, Antalya, Turkey

Manuscript received: 25.03 .2019 